\title{
Evasion of Children in Ivory Coast Artisanal Mining Activities
}

\author{
Kouame Joseph Arthur Kouame ${ }^{1}$, Yu Feng ${ }^{1}$, Fuxing Jiang ${ }^{1} \&$ Sitao Zhu ${ }^{1}$ \\ ${ }^{1}$ School of Civil and Environmental Engineering, University of Science and Technology Beijing, Beijing China \\ Correspondence: Kouame Joseph Arthur Kouame, School of Civil and Environmental Engineering, University of \\ Science and Technology Beijing, 30 Xueyuan Road, Haidian District, Beijing 100083, China. E-mail: \\ josepharthurkk.ustb@yahoo.com
}

\author{
Received: May 31, 2015 Accepted: September 8, 2015 Online Published: October 22, 2015 \\ doi:10.5539/jsd.v8n9p24 URL: http://dx.doi.org/10.5539/jsd.v8n9p24
}

\begin{abstract}
The development of the mining industry is necessary for the national GDP growth. The gold mining operation provides great support to local people in the construction of roads, hospitals and schools. However the damage caused due to the illegal gold mining in Ivory Coast has become increasingly worrying. Thousands of miners unlawfully exploit gold in many parts of the national territory. The local people, especially the children see artisanal gold mining as a faster way to get out of the growing poverty. According to the investigation with local people, MDA, mining companies, the rebellion in 2002 and the post-election crisis in 2010 were a key issue. As result of the political unrest many children have left school to move into the mining activities. This paper focuses on some existing problems relating to the minors in artisanal gold mine as well as how the illegal gold mining activities should increasingly concern the state's authorities who have to display their determination to stop this recurring phenomenon. In this paper, some suggestions will be proposed and we also support some initiatives and actions of the current government in order to reduce the rate of children or if possible to withdraw all the children from mining sites. The World Bank, financial institutions, NGOs are appealing too to play a major support role to eradicate child labor and to protect children in Ivory Coast and over the world.
\end{abstract}

Keywords: child labor, artisanal gold mining, Ivory Coast mining industry, impact of trafficking children

\section{Introduction}

Ivory Coast located in the western part of Africa has discovered the largest gold deposit with reserves estimated at 200 tons. The British company known as Amara Mining will extract its first gold in 2017 at Angovia a region of Yahoure, a village close to Yamoussoukro the state's political capital. The capital invested in this Angovia gold mine by Amara mining company is $\$ 400$ million. In addition to Angovia gold mining, this year (2013), Ivory Coast has opened the gold mining in the southwest of the country which is expected to surpass the national gold production from 13 to 16 tons per year. However the rebellion of 2002 and the post electoral crisis in Ivory Coast have had enormous consequences. This instability has made many children orphans. All these children without any proper formal background education left school to fend for themselves and due to this indulge in all kinds of negative activities. Most of them are oriented towards the artisanal gold mines without worrying about the immediate and prospective consequence because it pays for everything and supports their livelihood.

According to AGEPE on Thursday 26, 2014, the exact number of children involved in child labor in Ivory Coast is estimated to $1,994,593$. These are aged 13-17. The children used in agriculture sector are $53.4 \%, 35.6 \%$ in service and $11 \%$ in the industry. In fact $2 / 3$ of the children are into home job and this has a really negative impact on the education of the children. This investigation will enhance and extend the system of observation and monitoring of child labor in Ivory Coast (Yao, 2015).

The child trafficking generally leads to child labor. Minors have been working very young. According to the UNICEF statistics in 2011, at least 150 million children had been found in child labor. All those children from developing countries are aged between 5 to 14 years old (McAdam, M., 2013; Dillon et al., 2012).

As it had been reported by the International Labor Organization (I.L.O), $60 \%$ of children involved in child labor are working in the sector of agriculture. The number of children engaged in some hazardous work, such as the sex or drug trade is around 115 million (Rafferty, Y., 2013), Martens, M. (2012, Barna; S. M. 2012; World Bank Group 2012).

Some of the major forms of child labor include domestic issue, service, agriculture sector and manufacturing 
industries. Many children are everyday forced to work in restaurants, farms, factories, etc(Zensius, A., 2012).

The countries of West Africa and the Middle East remain the area where the trafficking of children is more recurrent. In these countries the right of children is not respected as reported the World Bank (World Bank, 2009). The United Nations Convention on the Rights of the Child had found much contradiction in a country like Zimbabwe. The begging of children in Zimbabwe is accepted largely by their parents (UNICEF, 2001; Muchini, B., 2001).

Ghana, a neighboring country of Ivory Coast is one of the largest gold producers in Africa. Many children including girls had been involved in the mining activities. Even if only some few details had been talked about the active involvement of girls in the mining activities in some part of Ghana such as Akwatia and Tarkwa as reported ILO in 2007, but this phenomena remains a great concern for the authorities (ILO, 2007; Bennett, et al, 2007). The community of Ghana and some NGOs had taken the excellent initiative to visit and check frequently all the territory of of Talensi Nadbam district which is almost $912 \mathrm{Km} 2$. As a result 150 children had been withdrawn from the mining sites (Hilson, G., 2008).

The political unrest in West Africa made this sub-Saharan area the prerogative location of illegal miners and the use of children as child labor is still on the rise (Hilson \& McQuilken, 2014). Two years after the rebellion the World Statistic has reported in 2004 that $35 \%$ of children aged 5 to 14 in Ivory Coast were in child labor. Today, despite the recognizable actions and efforts of the first lady of Ivory Coast Dominique Ouatarra in the program of protection of children, thousands of children between the ages 8 to 16 are in plantations and gold mine as employees (Edmonds, 2008; Ikejiaku, B. V., 2009).

As a result several cases of accidents and conflicts which led to violence were reported in the peripheries of the mining sites due to the activities of immigrants. The pollution due to the use of mercury and cyanide in illegal gold mining sites is resulting in the death of people. As typical example, we can figure out here the case of Sakassou in the central part of Ivory Coast (see Figure 1). Sakassou is $396 \mathrm{~km}$ away from Abidjan the economic capital and $71 \mathrm{Km}$ away from Yamoussoukro the political capital. Sakassou was invaded by illegal miners mostly from neighboring countries. Children, including over five minors were killed and four others seriously injured due to the collapse of an underground gold mine in Sakassou on Monday October 13, 2014. The victims were from Burkina Faso. They have been operating the clandestine mine for several year (AFP, 2014). 


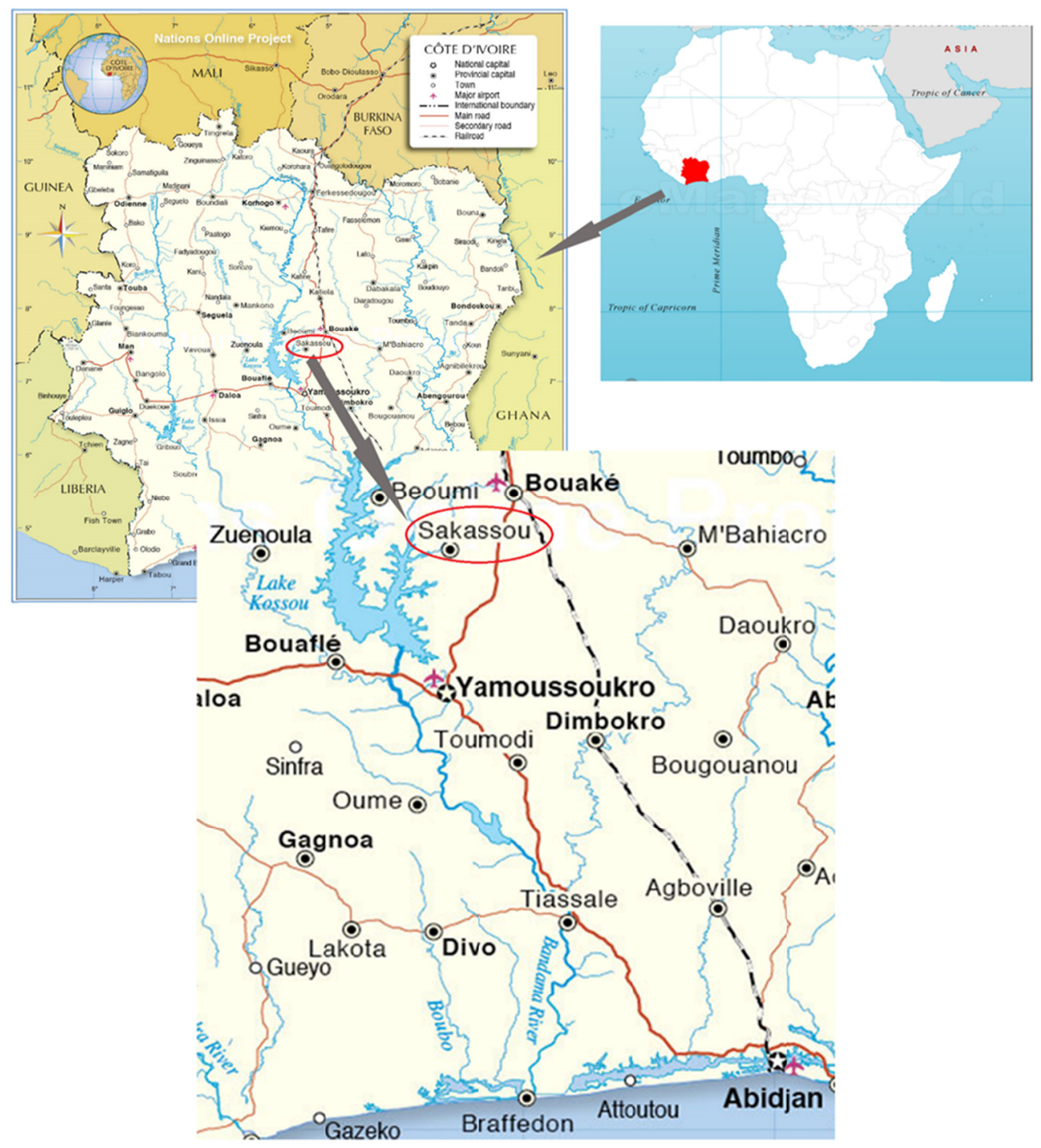

Figure. 1 The location of Sakassou

Due to the serious consequences that persist in this sector, the government together with the mining Ministry had taken a firm decision to immediately close all the illegal mining sites in Ivory Coast and had also instructed the security forces to carry out the arrest of several illegal miners on Monday, March 23, 2015. According to Ministry of Mines and Industry of Ivory Coast, It is almost 148 illegal sites operated by foreigners mostly from the West African sub-region in the Northern and Central part of Ivory Coast (see Figure 2). The western and Eastern part of the country will be checked in the future. The northern part of Ivory has the largest number of illegal such Kong with 63 illegal sites and Katioal-Niakara area with 33 sites. In the central part of the country such Toumodi and Yamoussoukro with 23 illegal sites, 14 sites at Tiebissou and 13 illegal sites in the zone of Bouafle, Divo, Hire. As a result, 1375 installations and 446 craft machines had been destroyed and 22 gauge shotguns seized 12 by the national police from 2013 to 2015. 


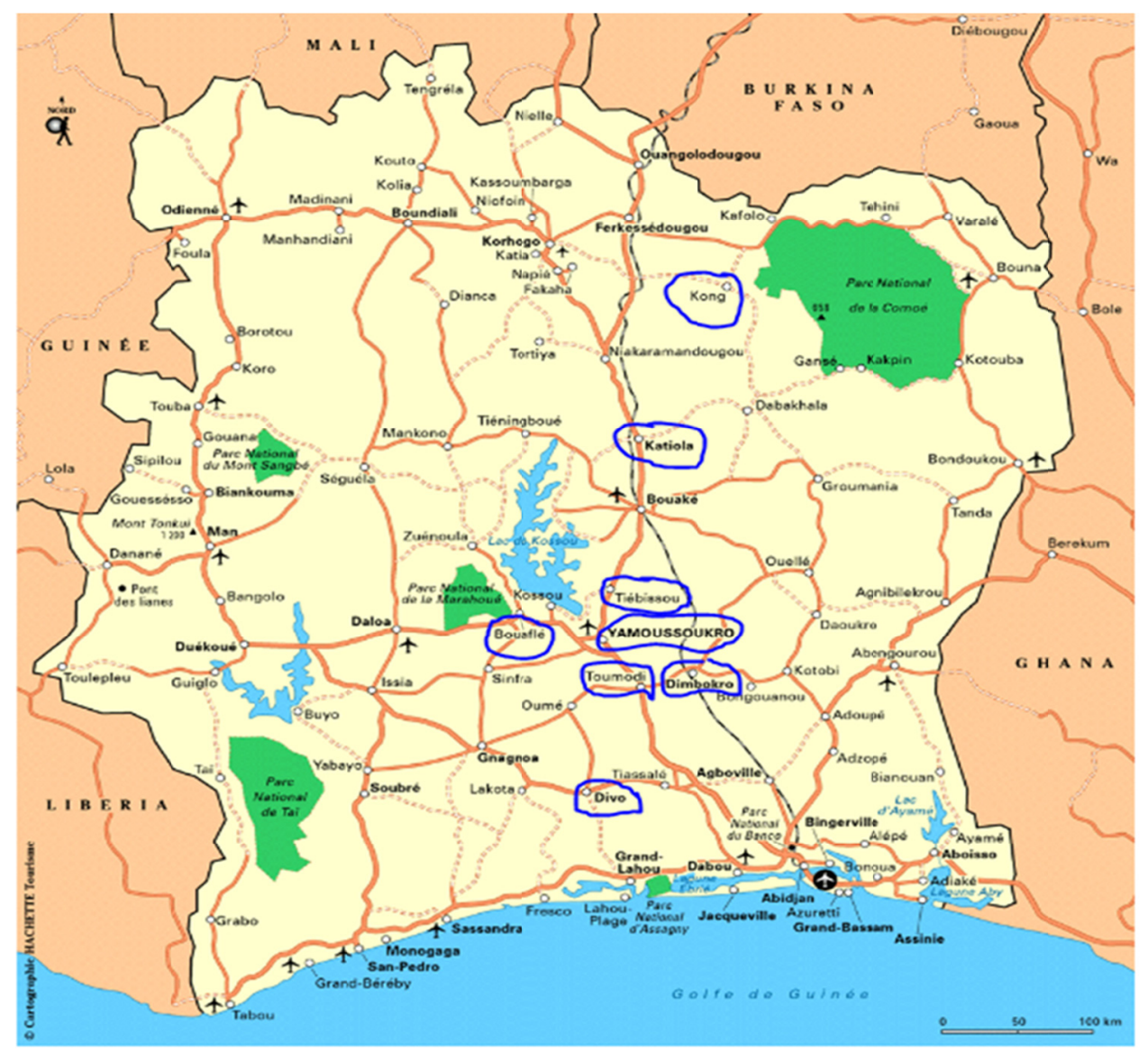

Figure 2. Some dismantled illegal mining sites in Ivory Coast (Ministry of mines and industry)

(Source Mining Ministry of Ivory Coast)

This present paper is trying to examine the growing influx of children in Artisanal mining activities in Ivory Coast. In this paper we will put forward some suggestions and also support some initiative of the government of Ivory Coast to reduce the rate of children in the illegal mining activities. The World Bank, financial institutions, NGOs should support the current government of Ivory Coast and the parents to withdraw children from mining sites.

\section{Research Methodology-Some Reasons of Influx of Children in Illegal Mining Activities}

Some of the major reasons of child labor (children in cocoa forms, mining activities...) in recent years include the high rate of population and orphans, unemployment, poverty and inadequate infrastructures.

\subsection{The High Rate of Population and Orphans}

The population growth rate in Ivory Coast is rising very fast (Figure 3). The population is 22,671,331 people according to the NIS report in 2014. The number of birth multiplies by the day. The high demographic rate and massive immigration from neighboring states constitute the major characteristics .Family planning is not followed because most parents are illiterates. The schools are insufficient to accommodate all children of school going age. The government struggles to find funds to build many schools since the borrowed funds from the World Bank, International Monetary Fund (IMF) are destined to address other issues such as security and health so the part destined to education remains insignificant., according to UNESCO statistics published on September 9, 2013, the illiteracy rate in Ivory Coast is around 51\% (Figure 3) which remains a serious obstacle to sustainable human development and the education in the country (AIP, 2013). Only $49 \%$ of the children are in school which means almost the half of children in Ivory Coast are not educated (Figure 3). Thousands of children have lost their progenitors during the political unrest between 1999-2011. Most of the orphans are not in orphanages and they do not have any support from the government and NGOs. They cater for themselves, they are uneducated, and they prefer to engage in other labor-intensive jobs. In spite of the high risks, their 
presence in illegal gold mining allows them to have a life better than banditry (see Geenen and Custers, 2010). In addition to above mentioned problems, Ivory Coast has become the destination of child trafficking from neighboring countries such as Burkina Faso, Mali and Ghana. Children have become goodwill for some parents and retailers. They promise a luxury life to children but once in Ivory Coast, all the children from those neighboring countries are used in plantations (coffee, cocoa, rubber ...) and in illegal gold mining sites (Edmonds, 2008 and HRW, 2012). This is one of the major issues leading to the presence of children being involved in illegal gold mines.

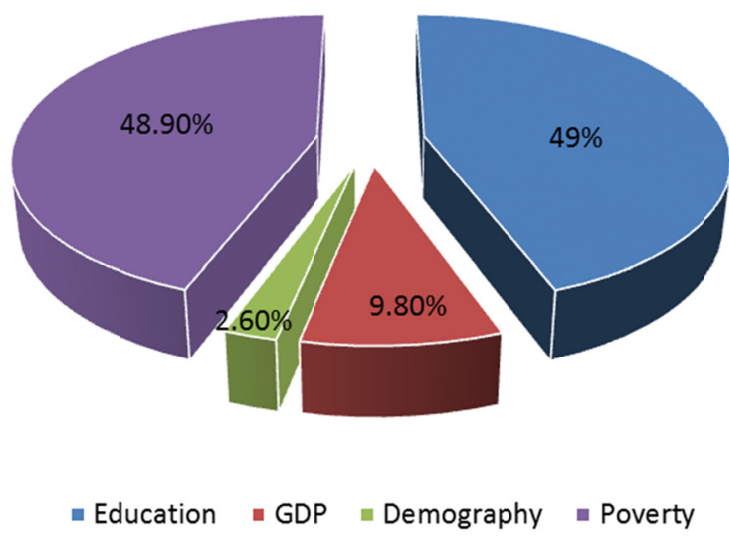

Figure 3. The rate of education, GDP, Demography and Poverty in Ivory Coast

\subsection{The High Rate Unemployment and Poverty in Ivory Coast}

According to the statistics of U.N (UN, 2005), many children are involved into child labor in Latin America, Africa and Asia. This is due to the fact that the poverty is intensive in these parts of the world.

Enrolment into school through pre-school, primary to postgraduate requires enormous financial commitment. Children and youth in the gold mines earn daily or monthly a considerable sum of money. As a result, children mostly from poor and low income families are encouraged by the parents go to the illegal gold mines in the hope of a better life without worrying that their children are in a vicious cycle of danger and despair.

The lack of employment after school as well as poverty does not encourage some parents to force their children to become more involved in school. They prefer to engage in quick ventures activities or informal sector to have quick financial resources (Banchirigah et al., 2010). The departure of many foreign companies and closures of some national companies is due to the political instability, meant that thousands of jobs were lost. The thorny unemployment problem due to this political unrest and post-election military crisis with its corollary effects such as economic crisis, social, financial had become a key factor of the abject poverty of some parents who cannot afford a proper education for their children. The half of the population of Ivory Coast is poor (Figure 3) and most of them are living in rural areas (Figure 4). This unemployed population today does not have sufficient financial means to care for their own children as well as ensure their development and their enlightenment. Hence they just choose to encourage them on working in illegal gold mining sites (United States Department of Labor, 2011).

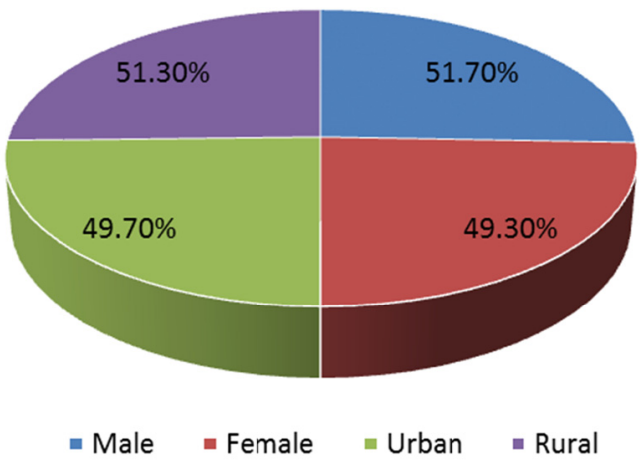

Figure 4. Statistic of the population in Ivory Coast 
Since the advent of multiparty politics in Ivory Coast in 1990, we assisted to constant and recurrent strikes of students and teachers which subsequently disrupted the normal functioning of the education system. The Universities are saturated due to the frequent invalid academic years. The living conditions of young people more than ever are complicated. The lack of youth employment policy and the mismanagement of the educational system are key factors in the movement of children and the sacrificed youth into illegal gold mines as a precipitant of distress, deprivation, and despair are accumulated over the years.

\subsection{The Inadequate Infrastructures}

Some children in Ivory Coast school are dropping outs urchins' due to the lower recruitment of staff into national payroll, the educational integration of young graduates into the job market increases each year. Recently the government of Ivory Coast even if is trying to build a lot of infrastructure to sustain schools and recruit as much as teachers for supervision and creating jobs for the integration of graduates into the workforce at the end of their academic and professional training but it still insignificant. The country is living largely by borrowing from the World Bank. (Brunnschweiler, C., 2008).

The northern region of the Ivory Coast, artisanal mining boom area has now many effects, resulting in many students dropping out of school to go for gold. This part of Ivory Coast is rich in Gold. Most of the populations in the northern of Ivory Coast are farmers and traders (Figure 4). They do not have much interest in education. The former rebels had occupied this part of the country and made it uncontrollable by the government during the political unrest. The laws and regulations were not respected in this part of Ivory Coast. The poverty rate is $77.3 \%$ in Korhogo a city located in the northern part of Ivory Coast and occupied by the rebels but the economic capital Abidjan in the southern has a poverty rate which is around $21 \%$ according to the recent investigation of NIS. The traffic of diamond was developed in this part of Ivory Coast by former rebels and local people including children were involved into mining activities to support their livelihood (and especially money...). The insecurity was growing up in this region. For this reasons the marketing of diamond in Ivory Coast was under UN embargo since 2005 (UN 2005).

Due to the political unrest which started with the rebellion in 2002, the poverty in Ivory Coast increased from $38.4 \%$ in 2002 to $48.9 \%$ in 2008 . The employment of young people, security, reintegration of former combatants and social cohesion are the main challenges of the current government (UN Security council, 2012). This 10 years crisis endured by the country has ruined its economy. Recently, the current government is seeking funds to cope with the serious insecurity that undermines the country and delaying the influx of investors to Ivory Coast. The soldiers from the former rebellion in that despite the disarmament, they continue to revolt and demand their integration in the country's social system. This situation makes the security of the country very fragile, so the government is actively concerned about solving the security issue in order to attract again the foreign investors and develop the country, while an important part of funds collected by the government and a good part of the national GDP are leading to solve the case of security. Therefore, the construction of schools and children education remains insignificant. The country's economy was really down during this period. Actually the national GDP is around 10\% (Figure 3) because the current government is actively involved in the development of the country. But it is very complex for a country like Ivory Coast which has many debts from the World Bank and other financial institutions to build more adequate infrastructures.

\section{Consequences}

Today in Ivory Coast, the strong influence of illegal gold mines on the young population is clear. The children are going to risk their lives every day in an arduous, painful and dangerous work without a proper intervention of Ivory Coast government, parents, stakeholders and the international community in the mining sector (United States Department of Labor, 2011). Many illegal mining companies exist in Ivory Coast, thousands of children work there. The diseases such as tuberculosis, HIV/AIDS are spreading while prostitution is developing in those operating sites. The death of children and insecurity are recurrent. This study predicts the further rise in illiteracy rate and taking note of the hazardous practices and the degradation of the environment (Webbink et al., 2012).

\section{Recommendations}

Nowadays, the obvious observation in Ivory Coast is that many children are employed in the area of illegal gold mines. The government should face this situation and make it a major concern because the reality of the risks is immense. The government should also accord importance to the youth, which is an important segment of our population through the creation of jobs.

\subsection{Child Protection}

In order to face this distressing situation of children in the gold mines activities and any forms of child labor, we 
highly suggest to the government of Ivory Coast to establish a rigorous social protection system for children, to create canteens in the majority of the country's schools which will help the poor children as most of the children are from poor families (Figure 3).

The funds disbursed by UNESCO for the children education should not be invest in some other sector but actively in education to make higher the rate of education. Education should be promoted and privileged in Ivory Coast. The government should make all public schools free or at least greatly reduce the education fee according to the population income which can allow parents to easily afford it. The Children of Africa Foundation created in 1998 by Dominique Ouattara with a view to change the lives of children i.e. to give every African child a better future should be a palpable example and encouraged by the authorities to reduce the rate of minors in the illegal mining.

The fight against Child labor should be the priority action of the state of Ivory Coast. The Government must imperatively get children out of illegal mining activities, as well as others sectors such as cocoa, coffee plantations and rubber trees. The government and NGOs should establish a national system in order to ensure the raising of children and should make the children's education their priority and create orphaned for those orphans resulting from the rebellion and post-election crisis At least 3.000 people died during the post-election crisis from December 2010 to April 2011. The government of Ivory Coast should have main objectives in the eradication of child labor and the protection of children because working in gold mines has many impacts on children's health. According to the UN classification in 2014, Ivory Coast 171st out of the 187 countries in terms of Human Development Index due to the fact the medical and educational structural in Ivory Coast remain very weak (UN, 2014). The government should adopt a fundamental decree for trafficking children and child labor law which will lead to respect the right of children in order to ensure the good livelihood of the all the children in Ivory Coast (Webbink, et al 2012 and UNOCHA, 2012).

The National Monitoring Committee and its partners, including agencies of the United Nations system, non-governmental organizations and businesses actors in the mining sector should pool their efforts to keep away children from illegal gold mining sites. The international community and development partners have committed to support the Government of Ivory Coast in the action to reduce the child labor rate. They should undertake a national communication campaign and training of prefects and all stakeholders to reframe children. The government with the support of the UNICEF and UNESCO should construct and rehabilitate schools close to the major gold mining sites and take a significant measure to ensure a good quality education for children and eradicate child trafficking from neighboring countries because the majorities of children in the gold mining are non-nationals (Werthmann, K., 2009). So today the steps taken by the authorities to close all the illegal mining sites is a great decision to ensure the control of mining industries and the consequences of the children in the illegal gold mining sites.

\subsection{Improvement of Population Living Conditions}

Today the economy of Ivory Coast is in ascendency. According to the statistics of World Bank, the national GDP was $8.7 \%$ in 2013 and $8.9 .8 \%$ in 2012 and will reach $10 \%$ in 2014. This is due to the fact the current government is actively in the involvement of the country's development. In order to help the parents schooling their kid, the population must benefit from the economy. "JEUNE AFRIQUE" had published on Wednesday November 12, 2014 that the government of Ivory Coast will allow almost 2.6 billion euros which are up $12.8 \%$ compared to 2014 , to the poor population in order to improve the livelihood and to strength the economy. This good action can be supported by some projects which leads diversification of the economy of Ivory Coast such as the development of the mining sector. We suggest to the current government to reorganize the mining sector through a lawful exercise of the mining activities. This rationalization programs in the mining sector will be a major key to attract foreign investors to the country because a good mining code always attracts investors (Bebbington, 2012). The government also should implement some projects to labor-intensive services which will lead distribution of jobs for people with minimal skills which will help many unemployed and people to have a job. If the majority of the population has monthly income, then they can easily take good care of their children and ensure their schooling fee. As they are aware of the risks of kids in mining activities, they will prefer to invest their income into education instead to encourage their children into mining activities.

The Government of Ivory Coast should solve the security issue which will lead to restoration of confidence and the cooperation with the financial institutions. These financial institutes will easily borrow funds to the country which will be invested in public investments in order to stimulate economic growth, including youth employment, boosting the private sector, development of the mining sector, creation of schools for kids and universities for youth. As a result the government will recover and reconstruct the economy of Ivory Coast. 
The government of Ivory Coast should encourage and finance youth entrepreneurship. The government can provide some capital to youth who have an excellent project to make their own business. This action will greatly reduce the youth unemployment and the abject poverty and the insecurity because youth can take care of themselves. In the northern part of Ivory Coast where the poverty rate is too high, the government should support the population to invest in some activities.

We Highly encourage the government and its mining ministry to continuously to close the all the illegal mining sites in all the parts of Ivory Coast in order to take a great step to streamline the mining sector and sanitize the artisanal mining by granting proper mining licenses. The recurrent conflicts between local people and miners will be ended and the use of some harmful chemical products by illegal miners such as mercury and cyanide which leads to death of people will be reduced.

It is also obvious that idle youth is a permanent threat to the stability and survival of the nation so the abolition of child labor is encouraged. The government should really focus on the education of children to ensure their bright future because as we all know, for lifeblood of tomorrow; children are the pedestal of development of the Ivory Coast and the whole world in general. The social and economic emergence of the Ivory Coast should be done with dynamic and dedicated youths. Young people should be spearheading the growth and development of the work; including entrepreneurship, instead being at the illegal gold mining sites, youth should be in school (Banchirigah et al,. 2010).

Finally we highly suggest to the NGOs, multinational companies and the governments to become actively involved in the fight against child trafficking and child labor in any form to reduce infantine mortality in Ivory Coast and around the world.

\section{Conclusions}

The expansion of child labor in illegal mining of gold in Ivory Coast is a serious political challenge. The political instability generated the high rate of unemployment and orphans who are desperately catering for themselves without support from NGOs, Government and even civil society. More so, the considerable lack of infrastructure since the event from December 1999 drives the rapid increase of children into the illegal mining activities throughout the extended national territory. This paper showed that the reduction of school fees, the promotion of jobs, the building of many infrastructures for youth and the security of all the national territory will highly reduce the influx of children in mining activities and also the child labor so the children in Ivory Coast will be protected and have a safe and quality education (Figure 5).

This study gives an overview of child trafficking in labor. Although the suggestions above are limited, the eradication of child labor and child protection should be a prime concern for the government. 


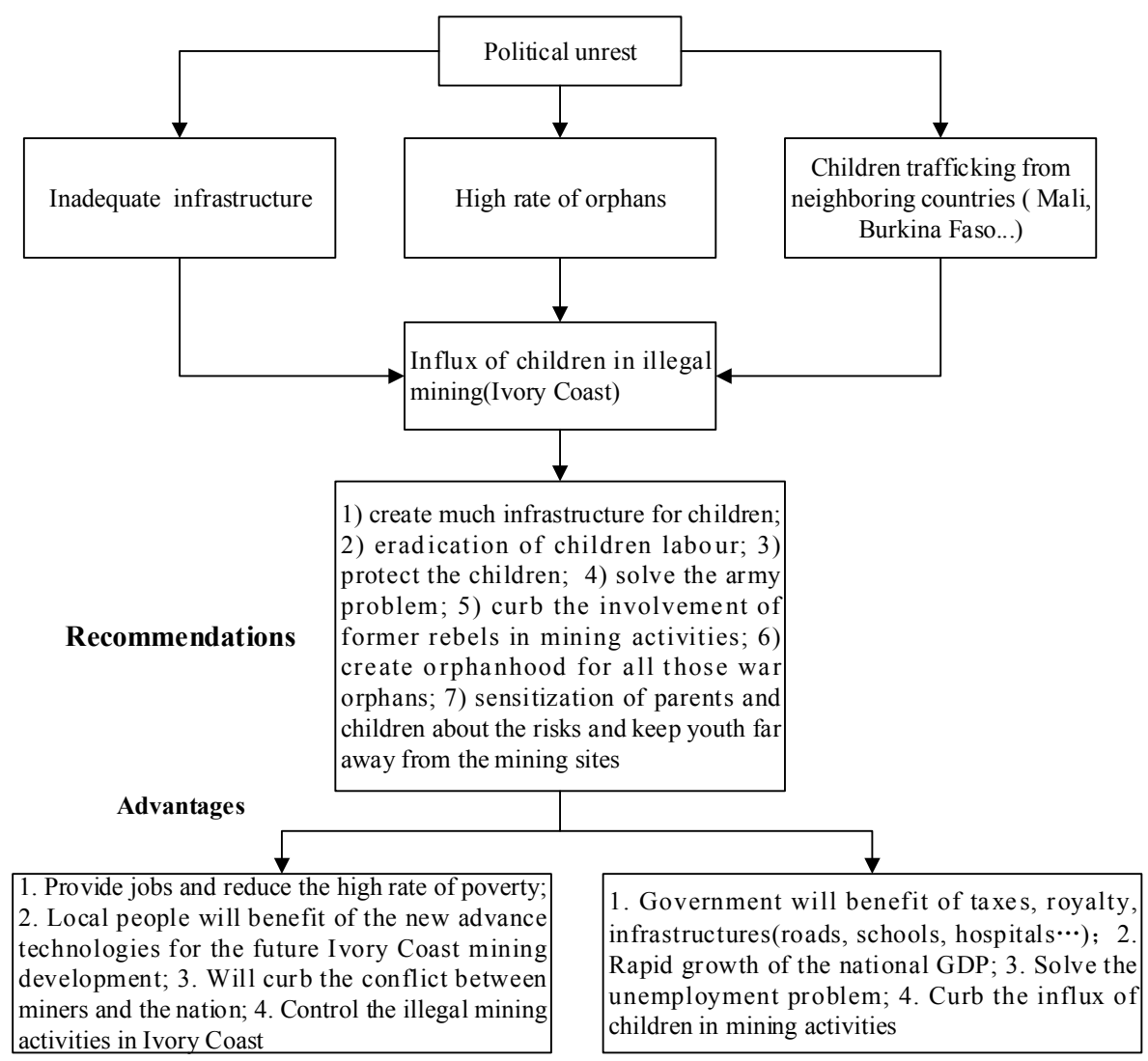

Figure 5. The conclusion structure

\section{Acknowledgments}

All praises to almighty God who gave us strength and abilities to complete this research work successfully. We would like to give our sincere gratitude to our honorable supervisor Prof. Fuxing Jiang for his continued assistance and good guidance time after time which made our thesis work become more precise and attractive. He supervises and gives us his spare time to discuss more about the problem of research work. We are grateful to CSC for the financial support, SODEMI and ITY MINES mining companies for their support in the collection of data. Finally, we would like to give thanks to Mr. Li BAOMING for the good relationship and the morale support.

\section{References}

AFP. (2014, October 17). Côte d'Ivoire: cinq morts dont des enfants dans l'éboulement d'une mine clandestine. Retrieved October 20, 2014, from http://news.abidjan.net/h/512785.html

AIP. (2013, September 9). L'Unesco annonce un taux d'analphabétisme de 51\% en Côte d'Ivoire (MENET). Retrieved December 2, 2013, from $\mathrm{http} / / /$ news.abidjan.net/h/471283.html

Banchirigah, S. M., \& Hilson, G. (2010). De-agrarianization, re-agrarianization and local economic development: Re-orientating livelihoods in African artisanal mining communities. Policy Sciences, 43(2), 157-180. http://dx.doi.org/10.1007/s11077-009-9091-5

Bebbington, A. (2012). Underground political ecologies: the second annual lecture of the Cultural and Political Ecology Specialty Group of the Association of American Geographers. Geoforum, 43(6), 1152-1162. http://dx.doi.org/10.1016/j.geoforum.2012.05.011

Bennett, S., Gilson, L., \& Mills, A. (Eds.). (2007). Health, economic development and household poverty: From understanding to action. Routledge. http://dx.doi.org/10.4324/9780203023570

Brunnschweiler, C. (2008). Cursing the blessings? Natural resource abundance, institutions, and economic growth. World Development, 36(3), 399-419. http://dx.doi.org/10.1016/j.worlddev.2007.03.004

Dillon, A., Bardasi, E., Beegle, K., \& Serneels, P. (2012). Explaining variation in child labor statistics. Journal of Development Economics, 98(1), 136-147. http://dx.doi.org/10.1016/j.jdeveco.2011.06.002 
Edmonds, E. V. (2008). Child labor. In T. P. Schultz, \& J. Strauss (Eds.), Handbook of Development Economics (Vol. 4, Chapter 57). North-Holland: Elsevier.

Factbook, C. W. (2015, January 1). Diagrammes Historiques de Données par Année. Consulté le January 6, 2015, sur INDEX MUNDI: http://www.indexmundi.com/g/g.aspx?v=24\&c=iv\&l=fr

Geenen, S., \& Custers, R. (2010). Tiraillements autour du secteur minier de l'Est de la RDC. In S. Vandeginste, F. Reyntjens, \& S. en Marysse (Eds.), L'Afrique Des Grands Lacs. Annuaire 2009-2010 (pp. 231-258). L'Harmattan, Paris.

Gozdiak, E. M. (2011). Data and research on human trafficking: Bibliography of research-based literature.

Hilson, G. (2008). Challenges with eradicating child labour in the artisanal mining sector: A case study of the Talensi-Nabdam District, Upper East Region of Ghana. Reading, University of Reading.

Hilson, G., \& McQuilken, J. (2014). Four decades of support for artisanal and small-scale mining in sub-Saharan Africa: a critical review. The Extractive Industries and Society, 1(1), 104-118. http://dx.doi.org/10.1016/j.exis.2014.01.002

Hoerrner, M., \& Hoerrner, K. (2012) Human Trafficking Sex Trafficking: A Clinical Guide for Nurses, 22.

HRW (Human Rights Watch). (2012). World report 2012: Events of 2011. New York. Retrieved from http://www.hrw.org/world-report-2012/world-report-2012-kazakhstan

Ikejiaku, B. V. (2009). The relationship between poverty, conflict and development. Journal of Sustainable Development, 2(1), 15. http://dx.doi.org/10.5539/jsd.v2n1p15

International Labor Organization (ILO). (2007). Girls in mining: Research finding from Ghana, Niger, Peru and the United Republic of Tanzania. Bureau for Gender Equality, International Programme on the Elimination of Child Labour, International Labour Organization, Geneva

Martens, M. (2012). Issues of access and usability in designing digital resources for children. Library \& Information Science Research, 34(3), 159-168. http://dx.doi.org/10.1016/j.lisr.2011.12.003

McAdam, M. (2013). Who's Who at the Border? A rights-based approach to identifying human trafficking at international borders. Anti-Trafficking Review, (2)

Muchini, B. (2001). A study on street children in Zimbabwe.

Rafferty, Y. (2013). Ending Child Trafficking as a Human Rights Priority: Applying the Spectrum of Prevention as a Conceptual Framework. Violence Against Girls and Women: International Perspectives [2 volumes]: International Perspectives, 133.

Selin, H. (2014). Global environmental law and treaty-making on hazardous substances: the Minamata convention and mercury abatement. Global Environmental Politics, 14(1), 1-19. http://dx.doi.org/10.1162/GLEP_a_00208

Spiegel, S. J., Savornin, O., Shoko, D., \& Veiga, M. M. (2006). Mercury reduction in Munhena, Mozambique: homemade solutions and the social context for change. International journal of occupational and environmental health, 12(3), 215-221. http://dx.doi.org/10.1179/oeh.2006.12.3.215

UNICEF. (2001).A study on street children in Zimbabwe. Evaluation report.

United States Department of Labor. (2011). 2010 findings on the worst forms of child labor. Washington, D.C. Retrieved from http://www.dol.gov/ilab/programs/ocft/PDF/2010TDA.pdf

UNOCHA (United Nations Office for the Coordination of Humanitarian Affairs). (2012). Kenya: 'Gold mining beats school any day. IRIN Humanitarian News and Analysis. Retrieved from http://irinnews.org/Report/94822/KENYA-Gold-mining-beats-school-any- day

Webbink, E., Smits, J., \& de Jong, E. (2012). Hidden child labor: Determinants of housework and family business work of children in 16 developing countries. World Development, 40(3), 631-642. http://dx.doi.org/10.1016/j.worlddev.2011.07.005

Werthmann, K. (2009). Working in a boom-town: Female perspectives on gold-mining in Burkina Faso. Resources policy, 34(1), 18-23. http://dx.doi.org/10.1016/j.resourpol.2008.09.002

World Bank Group (Ed.). (2012). World Development Indicators 2011. World Bank Publications. Chicago.

Yao, E. (2015, March 30). Situation du travail des enfants en cote d'ivoire: L'Agepe fait des revelations. Consulté le April 2, 2015, sur SOIR INFO- $\quad$ L'INTER: 
http://www.linfodrome.com/societe-culture/20209-situation-du-travail-des-enfants-en-cote-d-ivoire-1-agepe -fait-des-revelations

Zensius, A. (2012). Inside the Cocoa Pod: An Analysis of the Harkin-Engel Protocol in Cote d'Ivoire.

Zhang, M. (2012). The development of human resource management in China: An overview. Human Resource Management Review, 22(3), 161-164. http://dx.doi.org/10.1016/j.hrmr.2012.02.002

\section{Acronyms and Abbreviations}

SODEMI State Society for Development of the Mining Industry (Société pour le Développement Minier de la Côte d'Ivoire); UN United Nations; MDA Ministry Departments Agencies; NGO Nongovernmental Organization; AGEPE Promoting Employment and Study Agency (Agence d'Etude et de Promotion de l'Emploi); ILO International Labor Organization; NIS National Institute of Statistics (Institut National de la Statistique).

\section{Copyrights}

Copyright for this article is retained by the author(s), with first publication rights granted to the journal.

This is an open-access article distributed under the terms and conditions of the Creative Commons Attribution license (http://creativecommons.org/licenses/by/3.0/). 